\title{
Brexit: Measuring the Impact upon Skilled Labour in the UK Construction Industry
}

\begin{abstract}
Purpose - This paper presents an understanding of the potential impact of Brexit upon the United Kingdom (UK) construction industry. Specifically, the work analyses the construction industry's reliance upon European Union (EU) skilled labour and seeks to determine the potential impact that Brexit poses upon EU skilled labour entering the sector.
\end{abstract}

Research approach - A perceptual questionnaire survey was used to elicit responses from construction professionals using the two techniques of opportunity and snowballing non-probability sampling. Summary statistical analysis of Boolean and Likert item scale data accrued was employed to elucidate upon respondents' perceptions.

Findings - The majority of survey participants either 'strongly agreed' or 'agreed' that the UK construction industry relies upon EU skilled labour and that a career in the sector would not be attractive for foreign skilled labour post-Brexit. Future research proposed includes: predicting future trends in labour supply and demand and deriving new policies to address skills shortage imbalances that may be created by Brexit.

Originality - Original insight into an historic and unprecedented moment for the UK construction industry is presented. The work also provides pragmatic recommendations to policy makers and Higher Education Institutes to prevent the risk of Brexit further exacerbating skilled labour shortages within the industry.

\section{KEYWORDS}

Brexit, skilled labour, UK construction industry, skills shortages

\section{INTRODUCTION}

The construction industry represents a major contributor to the United Kingdom (UK) economy (Fien and Winfree, 2014; Levack, 2012; Hilling, 2015). It generates approximately $£ 90$ billion annually, which is equivalent to $6.5 \%$ of the UK's GDP 
(Rhodes, 2015). In addition, The Department for Business Innovation and Skills (DBIS) states that the construction industry: "employs in excess of 2.93 million people, the equivalent of about 10\% of UK employment" (DBIS, 2013, p.7). To maintain this status, the industry is heavily reliant upon skilled labour to complete and deliver infrastructure projects (Forde and MacKenzie, 2004; Rolfe and Hudson-Sharp, 2016). However, a recent report published by the Royal Institution of Chartered Surveyors (RICS), indicates that sector economic growth is being restricted by significant skills shortages (RICS, 2015). These skills shortages invariably affect the client's requirements in terms of time, cost and quality as the sector is heavily reliant upon its workforce (MacKenzie et. al., 2000; Chan and Dainty, 2007; Abdul Hamid et. al., 2011).

Against this backdrop, on Thursday $23^{\text {rd }}$ June 2016, the UK held a referendum vote to decide whether it should leave or remain within the European Union (EU). Wheeler and Hunt (2016) state that: "the referendum turnout was $71.8 \%$, with more than 30 million people voting" and resulted in the UK deciding to support Brexit and leave the EU. However, leaving the EU undoubtedly comes with potential consequences such as restrictions to free trade and access to the single market (Koch, 2016). Additionally, UK construction companies could potentially face barriers from other European countries when recruiting skilled labour due to potentially tighter immigration border controls (Palmer, 2016). This intensifies the retention and recruitment of EU skilled labour within the UK construction industry as $6.7 \%(142,502)$ of the total construction workforce are European nationals (Rolfe and Hudson-Sharp, 2016; Office for National Statistics, 2015). This imminent threat of reduced labour mobility, combined with the major shortage of indigenous skilled labour which the sector is currently experiencing, could negatively impact upon the UK construction industry's performance (Mohamed et. al., 2008; McLeod and Milne, 2016). An RICS survey conducted in Q2 of 2016 (post-Brexit) suggests that: "there was a slowdown in growth in Q2, with $56 \%$ of contributors reporting skills shortages as a constraint on growth" with bricklayers and quantity surveyors remaining in particularly short supply (RICS, 2016). Given historically volatile economic conditions within the sector and corresponding fluctuating labour demands, existing skills shortages could be further exacerbated by restricted access to overseas skilled labour (particularly given a heavy reliance upon labour from Eastern Europe) (Green, 2015; Kellaway et. al., 2016; Rolfe and Hudson- 
Sharp, 2016). As Green (2016) suggests: "the departure from the EU could spell a very serious shortage of labour, both skilled and non-skilled in the construction industry."

This paper reports an analysis into the potential impact of Brexit upon skilled labour in the UK construction industry. Concomitant objectives are to: assess the need for skilled labour (domestic and EU) within the UK construction industry; assess the potential impact of Brexit upon skilled labour entering the sector; and propose prescriptive recommendations that could minimise the risk Brexit poses upon skilled labour availability.

\section{REASONS FOR BREXIT AND DEMAND FOR SKILLED LABOUR}

The key driving forces behind the UK's decision to leave the EU has been cited as: significant hostility towards immigration and its potentially detrimental impact upon the economy due to 'benefit tourism'; and/ or the desire to retain national selfdetermination given widespread perceptions of a 'lack of control'(c.f. Tilford, 2016; Minford and Lyons, 2016; Springford, 2016). Other arguments centred upon a perceived preference for EU migrant workers over native British counterparts due to lower ('cheap') labour costs (Ruhs and Anderson, 2012). Somerville (2016) claims that an important socio-economic consideration is the UK public's concern regarding the ability of the government to manage and cope with migration competently. This has led to widespread disillusionment with the EU due to uncontrolled immigration (Tilford, 2016). Yet public perception has been contrary to industrial demand and the widespread view of UK practitioners that EU skilled labour has a superior work ethic and provides a reliable short-term solution to the sector's skills shortage (Rolfe and Hudson-Sharp, 2016). Indeed, EU skilled labour was intentionally incentivised to work in the UK construction industry (Migration Advisory Committee, 2014). Reasons for this are myriad, but Dixon (2003) reports skills disparity amongst tradesmen to be a prominent issue whilst O'Donnel et. al, (2008) suggest that retiring baby-boomers further increased demand for skilled labour. The majority of UK construction companies recognise that migration from Eastern Europe plays a major role in filling the construction industry's skills shortage (Branson, 2016). Furthermore, Ruiz (2004) adds that whilst EU migration may 'fill a gap' in the UK's labour shortages, it does not have a detrimental impact upon the economy. However, while contemplating the labour supply shortfall, McKay et al., (2012) comment that EU skilled labour has become 
dominant in the construction industry thus increasing demand for migrant workers (Belman, 2013; Vargas-Silva, 2016). This ongoing academic discourse highlights the importance of the issue of non-UK skilled labour (UKCES, 2014; Ferry, et. al., 2016).

Table 1 provides a succinct synthesis of extant literature to illustrate both the positive and negative connotations regarding the free movement of people and EU skilled labour. Opinions are distinctively polarised, for example, Portes (2016) contends that the free movement of people is highly beneficial for the UK construction industry's skilled labour force. This view is supported by McLeod and Milne (2016) who assert that overseas recruitment of immigrant labour is needed to address the perpetual skills shortage that appears alongside the wild perturbations in the industry's economic fortunes. In contrast, Springford (2013) states that "free movement is no longer perceived to be an arrangement that works for the mutual benefit of both Britons and other Europeans." However, despite Brexit uncertainty, office construction boomed in London post-Brexit, indicating that any negative impact could potentially be sector or region based (Patnaude, 2016). Street (2016) forecasts that any notable impact of Brexit upon skilled labour shortages may occur during 2017-2018 since Article 50 has been triggered. If this prediction is valid, then the industry's ability to meet the Government's infrastructure projects (such as regional housing projects and HS2) could be hindered (Daly, 2016). Any additional shortage of skilled labour would further exacerbate labour requirements (UKCES, 2014), increase construction costs (Rolfe and Hudson-Sharp, 2016) and elevate the risk of delayed construction projects (Baillie et. al., 2016).

<Insert Table 1 about here>

At present, and given contemporary political agendas, it is highly unlikely that the free movement of people arrangement between the UK and EU will remain in place postBrexit (Rolfe and Hudson-Sharp, 2016). However, Brexit negotiations have only just commenced between the UK and EU and calm reflection may alter the mind-set of individuals regarding the importance of skilled labour as a vital factor for the construction industry and wider UK economy (Swales and Baker, 2016).

\section{THE TYPE OF BREXIT AND ITS CONSEQUENCES}


There is currently a high degree of uncertainty about the 'type' of Brexit (i.e., 'soft' or 'hard') that the UK is likely to enforce (Fichtner et. al., 2016) (refer to Table 2). The UK Prime Minister (Theresa May), reflecting a broad base and the 'leave' constituency, has stated that: "Brexit means Brexit" and that she will make a success of it - albeit the process could take up to two years to complete (Dominiczak and Wilkinson, 2016). However, there is considerable uncertainty as to whether the construction industry will continue to have access to the free movement of EU workers (Oliver, 2016). Lack of access could be problematic for a sector that is already at a labour-skills crisis point (Branson, 2016). Migrant restrictions could divert EU labour to alternative EU countries with lesser restrictions on migrant labour (Wilson, 2016). Despite this risk, some form of restriction upon EU immigration may be implemented as this issue remains an omnipresent political 'football' that has driven the UK Government's agenda and possibly the type of Brexit ultimately adopted (Wisniowski, 2016; Koch, 2016; Swales and Baker, 2016). An antithesis to negative consequences reported is propagated by Marley (2016) who suggests that Brexit will reduce bureaucratic red tape thus facilitating greater trade with countries outside the EU. Wood (2016) comments that withdrawing from the EU could also benefit UK construction workers as access to a broader portfolio of job opportunities could become available and wage rises may ensue. One of the UK's primary aspirations is to remain a member of the single market (Emmerson et. al., 2016). However, European Commission spokespeople (particularly Jean Claude Juncker, European Commission President) have numerously stated that if the UK wishes to retain this membership, it must accept the free movement of people (Swales and Baker, 2016).

<Insert Table 2 about here>

Renewed calls to increase construction industry productivity, have engendered momentum to improve labour skill levels, enhance trade qualifications and deliver a multi-skilled workforce (Campbell et. al., 2001). Although skilled EU migrant labour is a short-term solution to a shortage of skilled labour (Metcalf et. al., 2010), a longerterm need must be to augment the training, education and competence of indigenous workers (Hilling, 2015). A career in construction remains unpopular among the younger generation for a number of reasons including: parental influence; the poor image of construction; and an ageing workforce (Hilling, 2015; Johnson, 2013). The demand for 
skills could be met through the recruitment of the younger generation but the aforementioned perceptions and problems must first be addressed. To some extent, this is being addressed through the significant expansion of the apprenticeship base in the UK and the development of apprenticeship standards. The needs and the methods to retain skilled labour, as reported upon within the extant literature, are depicted in Figure 1.

$<$ Insert Figure 1 about here>

\section{RESEARCH APPROACH}

An inductive methodology was adopted using a mixed methods approach (as adopted by Tashakkori and Teddlie, 2003). It should be noted that where a mixed methods approach is used, it resembles the third methodological movement or the third paradigm (Adolphus, 2005). This approach combines quantitative and qualitative methods and techniques sequentially into a single study (Johnson and Onwuebugzie, 2004; Creswell, 2003; Yin, 2006). Palpable benefits to be derived include that it: provides a better understanding of research problems (Creswell, 2003; Woolley, 2009); yields more complete evidence and strengthen findings (Adolphus, 2005); captures in-depth views and experiences from participants about the subject matter under investigation (Jogulu and Pansiri, 2011; Farrell, 2011); and is inherently flexible, capturing pertinent data and enabling comprehensive analysis (King, 1994).

\section{Data collection, sample design and pilot work}

The survey method is the most frequently used form of qualitative research and is concerned with present phenomena as opposed to historical research and past events (Janes, 2001; Farrell, 2011). This unique characteristic of survey research makes it suitable for the proposed topic. Rowley (2014, p.310) indicates that: "questionnaires are typically used in survey situations" and this incorporates a predefined series of questions within a questionnaire data collection instrument to gather the perceptions and views of construction industry professionals (Jankowicz, 2004; Trochim, 2002). Questionnaires are a highly effective method of data collection (Bird, 2009) and a: "convenient way of collecting useful comparable data from a large number of individuals" (Mathers et. al., 2007, p.20). The questionnaire itself was self- 
administered as this offers the least expensive mode of collecting data (Nakash et. al., 2006).

The developed questionnaire consisted of closed-ended questions, which typically yield a higher completion percentage when compared to open-ended questions (Reja et. al., 2003; Friborg and Rosenvinge, 2013). Given an absent interviewer, open-ended questions could also be problematic because: i) more effort is required from respondents (Reja et. al., 2003); and, ii) more missing data could be produced (Friborg and Rosenvinge, 2013). The closed-ended questions consisted of one of two five-point Likert items (namely either 1 - i) strongly agree; ii) agree; iii) neutral; iv) disagree; and v) strongly disagree or 2 - i) very positively; ii) positively; iii) neutral; iv) negatively; and v) very negatively). Some dichotomous questions also had the requirement to explain the reason for choosing 'yes' or 'no' to the respective question in order to gain insight into the reason for the choice.

A pilot study was implemented for this work to pre-test the proposed research data collection instrument (i.e., a questionnaire) and ensure overall success of the approach (van-Teijlingen and Hundley, 2004; Lancaster et. al., 2004). Additionally, this approach partially validates the reliability of the research tools used (Rennie et. al., 2001). Opportunity sampling was selected for the pilot work (Biernacki and Waldrof, 1981; McLeod, 2014) and five responses were sought from practicing construction professionals (namely: one construction manager; two project managers; one site manager; and one quantity surveyor) (McLeod, 2014). Questionnaires were delivered by hand delivery and email. The invitation to complete the questionnaire contained a brief description of the proposed research, its aim and what the research outcomes aspired to achieve. All five participants responded, indicating that the questionnaire was straightforward, easy to interpret and interesting to complete.

For the main study, the technique of snowball sampling was employed which consists of identifying respondents for the questionnaire who then refer the researcher to other respondents and so forth (Atkinson and Flint, 2001). Initially, respondents were obtained from the 'Building Birmingham Scholarship' which is an education trust that helps young people (from impoverished backgrounds) commence their education and career in construction. At trust meetings, young people are able to network with 
industry practitioners and recruitment consultants. Snowballing was advantageous in this context as the 'networking and linkages' opportunities offered by this trust enabled the lead researcher to gain knowledge of prominent individuals within the sector (Elbers and Jarillo, 1998). Construction personnel targeted included: clerk of works; consultants; designers; engineers; project managers; planners; surveyors; and labour personnel.

\section{DATA COLLECTION AND ANALYSIS}

To ensure that strict ethical considerations were adhered to, participants were not asked to provide their name, specific age or employer details. Participants were also reassured that: i) they could withdraw from the study at any stage in the process; ii) all data collected would be securely disposed of once analysed and published; and iii) any personal details disclosed voluntarily would be kept strictly confidential (Oliver, 2010). A total of 63 questionnaires were distributed to construction personnel, with 51 respondents completing the questionnaire. Data was collected over a period of 45 days and a high $80.95 \%$ response rate was recorded. Anecdotal evidence suggests that this high response rate is associated with the interest, uncertainties and current relevance of Brexit from personnel within the construction industry. Additionally, it is partly associated with the extensive networking links available to the researchers (within the Building Birmingham Scholarship) and the snowballing sampling method employed.

Quantitative data was analysed using summary statistical analysis to afford expedient and simple description of the data (Clarke and Warwick, 2001). Qualitative data was analysed using componential analysis, where this technique assumes that: "the meaning of any given word is represented the best by a unique bundle of meaningful features" as stated by Beck et. al., (2004, p.1). Componential analysis creates ample scope to examine the ensuing discourse amongst practitioners (Morse, 1994). To augment the qualitative component of the research conducted, a focus group consisting of practitioners was employed at one local construction contractor. The feedback received from the focus group also served to validate the research findings (Zimmerman et. al., 1990; Barker and Rich, 1992; Kitzinger, 1994; Curry et. al., 2009). Focus group feedback also enabled the generation of pragmatic recommendations and provided direction for future research (Kitzinger, 1994). 


\section{SURVEY FINDINGS AND DISCUSSION}

All respondents claimed to have experience of working within the construction industry ( $\geq 5$ years) and were confident to report upon the potential impact of Brexit and the supply of skilled labour (refer to Table 3a). The largest age-range group of respondents was those aged between 25-35 years (refer to Table $3 \mathrm{~b}$ ). The high response rate from this age-group could be due to an elevated level of interest from younger to middleaged professionals. Table $3 \mathrm{c}$ illustrates that quantity surveyors (with 22 no. responses) represented the largest group of participating respondents, followed by: managers (13 no. responses); labour personnel (5 no. responses); clerk of works and designers (2 no. responses each); engineers (3 no. responses); and consultants (4 responses). Surveyors and managers had a higher response rate because the topic under investigation impacted upon their professional occupation. Anecdotal evidence suggests that quantity surveyors were interested to determine whether a labour shortage would increase labour (and consequently, project) costs. Similarly, managers sought to determine whether the influx of European skilled labour would cease or be limited in the future - such resource limitations have major ramifications upon delivering a programme of works on time and to a desired level of quality.

<Insert Tables 3a, $3 \mathrm{~b}$ and $3 \mathrm{c}$ about here>

A set of dichotomous ('yes' or 'no') questions were answered by respondents on key Brexit issues (refer to Table 4). Interestingly: $88 \%$ of respondents (frequency $(f) 45$ no.) felt that a labour shortage would affect the UK construction industry; 88\% ( $f=45$ no.) believed that the UK relied upon EU skilled labour; and $86 \%(f=44$ no.) expected to see an increase in demand for skilled labour post Brexit. These compelling statistics are most likely due to the respondents' experience of historical skills shortages that have plagued the UK construction sector and previous reliance upon skilled labour from Europe (Forster, 2014). Survey results therefore reveal that most participating construction professionals overwhelmingly believe that the construction industry's supply of skilled labour will be affected by Brexit.

<Insert Table 4 about here> 
Respondents were then asked to rate key statements pertinent to Brexit and the issue of skilled labour supply and demand using a five-point Likert item to determine their level of agreement (refer to Table 5). Headline statistics reveal that a large number of respondents believe that (in order at which statements were posed): the free movement of people is beneficial to the UK construction industry (i.e., 92\% either strongly agreed or agreed with this statement); the UK construction industry would be less attractive than other EU construction markets for migrant labour (i.e., 90\% ditto); access to skilled labour would be reduced (i.e., 96\% ditto); and government infrastructure projects would not be delivered (i.e., $82 \%$ ditto). Whilst some of these perceptions may not become reality, they will almost certainly reduce morale within the sector. Cumulatively, the extant literature and research findings are summarised in Figure 3 - there will undoubtedly be some causal interaction and linkages between these factors and variables and future research will be required to measure the extent of such.

<Insert Table 5 and Figure 3 about here>

Academic discourse contends that a plethora of negative implications are associated with Brexit. These implications include: the UK industry's unattractive image/ appeal for EU labour (Kellaway et. al., 2016; Green, 2016, Tilford, 2016; Goodwin and Heath, 2016); an increase in skilled labour demand (Ferry et. al., 2016; Portes, 2016); a decrease of project quality (Wood, 2016, Wilson, 2016, Koch, 2016); reduced access to skilled labour (Sommerville, 2016; Swales and Baker, 2016; Branson, 2016); an inability to meet governmental projects (Rolfe and Hudson-Sharpe, 2016); and a decrease in industry growth (Wedderburn, 2016; Dominiczak and Wilkinson, 2016; Marley, 2016). Research findings presented support this academic discourse and the voice of practitioners (regardless of their occupation, age group and/or experience) forms a general consensus that the UK construction industry relies upon EU skilled labour. The research results were presented to the focus group participants for comment and feedback; all concurred with the findings and substantiated their views with reference to their own personal experience of working in the industry and managing foreign skilled labour. One focus group member said:

"I definitely agree that Brexit will impact upon skilled labour coming to this country [the UK] to work." 
Another focus group member added:

"I believe that this will lead to an intensification of the current skills crisis and could well lead to increases in labour and project costs."

These findings notably contradict a narrow Brexit victory vote and several reasons may be apparent. Public opinion that was once polarised over this issue may have started to lean towards a more sympathetic stance towards the EU and a desire to take a softer Brexit stance. Equally, professional opinions reported upon herein may simply reflect a microcosm that is the construction industry - far detached from wider public perceptions. After all, the construction industry is ubiquitously characterised as being bespoke and laden with multiple idiosyncratic and distinguishing features that make it unique.

\section{CONCLUSIONS}

The extant literature and questionnaire results confirm that widespread industry opposition against Brexit prevails; many perceive that Brexit will reduce the supply of skilled labour from the EU rather than increase or enhance it. Viewpoints of practitioners and the extant literature further substantiate and underscore the industry's dire need for skilled labour. Cumulatively, this discourse with practitioners demonstrates the industry's reliance upon EU skilled labour and that the negative connotations of Brexit (and the unattractive image it portrays) may repel EU skilled labour from entering the industry. To overcome the detrimental impact that Brexit could have by further exacerbating an omnipresent skills shortage, it is recommended that the free movement of people is retained, which can be achieved if the UK joins the European Free Trade Association (EFTA) and remains part of the European Economic Area (EEA). This option would ensure the free movement of goods, services, persons and capital whilst placating calls for stronger national sovereignty. Existing indigenous skilled labour should also be retained through the implementation of incentives such as increased wages, guaranteed overtime opportunities or reducing physical exertion via the implementation of technology and automation. To attract future generations of indigenous and/or foreign skilled labour, the image of a career in construction requires all-embracing reform. Advanced technological innovations (such as automation to reduce manual labour) should be marketed more effectively to young people to 
demonstrate the opportunities available to them. However, it is also apparent that the recurrent 'boom-and-bust' nature of the sector presents a systemic problem that grossly aggravates the skills shortage conundrum. Perhaps long-term Government infrastructure planning reform could lessen the impact of such wild economic perturbations, but in today's global economy, such may, merely, act as a buffer vis-avis a panacea to economic fortunes.

In solving the initial research aim, further questions and directions for future work have transpired - namely to: i) measure the actual impact (via labour trends analysis and other inferential/ deterministic statistics) of Brexit upon skilled labour within the UK construction sector (vis-a-vis perceptions); ii) derive new and pragmatic policies to correct skills shortage imbalances that may be created by Brexit; iii) develop innovative and attractive methods through which to encourage indigenous (and future) tradesmen and tradeswomen to commence a long-term career in construction; and iv) investigate whether Government grants and construction related funding from prominent organisations are being used effectively and efficiently.

\section{ACKNOWLEDGEMENTS}

Thank you to Miss P.G. Spittle, OPERC and Professor Gareth Neighbour, Birmingham City University for their constructive comments, suggestions and various editorial contributions.

\section{DEDICATION}

This paper is dedicated to June Edwards [3/12/1947 to $13 / 5 / 2017]$ - a mother rich with unconditional love, gifted with intellect and graced with elegance and beauty. 


\section{REFERENCES}

Abdul-Hamid, A, Singh, B, Yusof, A. and Abdullah, N. (2011) The Employment of Foreign Workers at Construction Sites, $2^{\text {nd }}$ International Conference on Construction and Project Management, Vol. 15, pp. 126-130. IACSIT Press, Singapore. Available via: http://www.ipedr.com/vol15/25ICCPM2011A00047.pdf [Accessed: May, 2017].

Adolphus, M. (2005) How to Use... Mixed Methods Research. Emerald Publishing: Bradford. Available via: http://www.emeraldgrouppublishing.com/research/guides/methods/mixed_meth ods.htm [Accessed: May, 2017].

Atkinson, R. and Flint, J. (2001) Accessing Hidden and Hard-to-reach Populations: Snowball Research Strategies, Social Research, Vol. 33. Available via: http://sru.soc.surrey.ac.uk/SRU33.pdf [Accessed: May, 2017].

Baillie, R, Atchinson, S. and Taylor, L. (2016) EU Referendum: Brexit and the Impact on UK Infrastructure, Squire Patton Boggs. Available via: http://www.squirepattonboggs.com/ /media/files/insights/publications/2016/06/ eu-referendum-brexit-and-the-impact-on-ukinfrastructure/eureferendumukinfrastructurealert.pdf [Accessed: May, 2017]

Barker, G. and Rich, S. (1992) Influences on Adolescent Sexuality in Nigeria and Kenya: Findings from Recent Focus-group Discussions. Studies in Family Planning, Vol. 23, No. 1, pp.199-210. DOI: 10.2307/1966728

Belman, B. (2013) Skilled Labour Shortage in the Construction Industry? It's not Demonstrated in the Numbers. The Construction Index: School of Human Resources and Labour Relations, Michigan State University. Available via: https://www.leg.state.nv.us/App/NELIS/REL/79th2017/ExhibitDocument/Open $\underline{\text { ExhibitDocument?exhibitId=30799\&fileDownloadName=0220b_staw.pdf }}$ [Accessed: May, 2017].

Biernacki, P. and Waldorf, D. (1981) Snowball Sampling: Problems and Techniques of Chain Referral Sampling, Sociological Methods Research, Vol. 10, No. 2. pp.141-163. Available via: http://www.columbia.edu/itc/hs/pubhealth/p8462/misc/biernacki_lect4.pdf [Accessed: May, 2017].

Branson, A. (2016) Who will Build our Homes? Brexit Could Spell Disaster for a Construction Sector Already at Crisis Point in Terms of Manpower, Property 
week, Available via: http://www.propertyweek.com/insight/analysisfeatures/housebuilding-who-will-build-our-homes?/5084437.article [Accessed: May, 2017].

Campbell, M, Baldwin, S, Johnson S, Chapman, R, Upton A. and Walton, F. (2001) Skills in England: The Research Report. Policy Research Institute. Available via: http://webarchive.nationalarchives.gov.uk/20130401151715/http://www.educati on.gov.uk/publications/eOrderingDownload/SIE-2001-RR.pdf [Accessed: May, 2017].

Chan, P. and Dainty, A. (2007) Resolving the UK construction Skills Crisis: A Critical Perspective on the Research and Policy Agenda. Construction Management and Economic. Vol. 25, No. 4, pp.375-386. DOI: 10.1080/01446190600863152

Clarke, K. and Warwick, R. (2001) An Approach to Statistical Analysis and Interpretation. $2^{\text {nd }}$ Ed. Primer-E: Plymouth Marine Laboratory. ISBN-10: 1855311402

Creswell, J. (2003) Research Design: Qualitative, Quantitative and Mixed Methods Approaches. $2^{\text {nd }}$ Ed. Thousand Oaks, Sage: London. ISBN 10: 1452226105

Curry, L, Nembhard, I. and Bradley, E. (2009) Qualitative and Mixed Methods Provide Unique Contributions to Outcomes Research. Journal of Mixed Methods. Vol. 119, No. 10, pp. 1442-1452. DOI: 10.1161/CIRCULATIONAHA.107.742775

Daly, S. (2016) The Taxing Consequences of Brexit. King's Law Journal, Vol. 27, No.

3, pp. 463-472. DOI: 10.1080/09615768.2016.1249110

DBIS (Department for Business, Innovation and Skills) (2013) UK Construction: An Economic Analysis of the Sector, p. 7. Available via: <https://www.gov.uk/government/uploads/system/uploads/attachment_data/file/ 210060/bis-13-958-uk-construction-an-economic-analysis-of-sector.pdf>

[Accessed: October, 2016]

Dixon, S. (2013) The Implications of Population Ageing for Labour Market. Office for National Statistics. DOI: 10.1177/1473325003002002003

Dominiczak, P. and Wilkinson, M. (2016) Theresa May says Britain must Look Beyond Europe - as She Vows to Trigger Article 50 by March. Available via: <http://www.telegraph.co.uk/news/2016/10/02/theresa-may-brexit-borisjohnson-david-davis-liam-fox-live/> [Accessed: November 2016] 
Ebers, M. and Jarillo, C. (1998) The Construction, Forms and Consequences of Industry Networks. International Studies of Management and organisations, Vol. 27, No. 4, pp. 3-21. DOI0: http://dx.doi.org/10.1080/00208825.1997.11656716

Emmerson, C, Johnson, P. and Mitchell, I. (2016) The EU Single Market: the Value of Membership Versus Access to the UK. Institute for Fiscal Studies: Economic and Social Research Council. DOI: 10.1920/re.ifs.2016.0119

Farrell, P. (2011) Writing a Built Environment: Dissertation Practical Guidance and Examples. Wiley-Blackwell, Chichester: West Sussex. ISBN: 978-1-4443-28677

Fichtner, F, Grobe-Steffen, C, Hachula, M. and Schlaak, T. (2016) Brexit Decision is Likely to Reduce Growth in the Short Term. Econstor, p.1. Available via: https://www.diw.de/documents/publikationen/73/diw_01.c.538245.de/diw_econ _bull_2016-26-3.pdf [Accessed: May, 2017].

Fien, J. and Winfree, T. (2014) Drivers of Change in Construction Training: How Significant is the Sustainability Agenda? Prospect Quarterly Review of Comparative Education, Vol. 44, No. 2, pp.211-219. DOI: 10.1007/s11125-0149304-3

Forde, C. and MacKenzie, R. (2004) Cementing Skills: Training and Labour use in UK Construction, Human Resource Management Journal, Vol. 14, No. 3, pp. 74-88. DOI: 10.1111/j.1748-8583.2004.tb00127.x

Forster, G. (2014) Construction Site Studies: Production Administration and Personnel. Routledge: London. ISBN-10: 0582019710

Friborg, O. and Rosenvinge, J. (2013) A Comparison of Open-ended and Closed Questions in the Prediction of Mental Health, Vol. 47, No. 3, pp. 1397-1411. DOI: $10.1007 / \mathrm{s} 11135-011-9597-8$

Goodwin, M.J. and Heath, O. (2016) The 2016 Referendum, Brexit and the Left Behind: An Aggregate-level Analysis of the Result, The Political Quarterly. Vol. 87, No. 3, pp. 323-332. DOI:10.1111/1467-923X.12285

Green, B. (2015) CIOB Perspectives: An Analysis on Migration in the Construction Sector. Chartered Institute of Building, p.16. Available via: https://policy.ciob.org/research/ciob-research-analysis-on-migration-in-theconstruction-sector/ [Accessed: May, 2017]. 
Green, J. (2016) The Outlook of The UK Construction Industry, The Market Mogul. Available via: http://themarketmogul.com/outlook-uk-construction-industry/ [Accessed: May, 2017]

Hilling, R. (2015) Is There a Skill Shortage in the Construction Industry? Available at: $<$ http://www.agencycentral.co.uk/articles/2015-11/skill-shortages-inconstruction-industry.htm [Accessed: October, 2016].

Janes, J. (2001) Survey Research Design, Library Hi Tech, Vol. 19, No. 4, pp. 419421. DOI: 10.1108/eum0000000006543.

Jankowicz, A. (2004) Business Research Projects. $4^{\text {th }}$ Ed. Cengage Learning: London. ISBN-10: 1844800822

Jogulu, U. and Pansiri, J. (2011) Mixed Methods: A Research Design for Management Doctoral Dissertations, Management Research Review, Vol. 34, No. 6, p.667701. DOI: $10.1108 / 01409171111136211$

Johnson, B. and Onwuegbuzie, A. (2004) Mixed Methods Research: A Research Paradigm Whose Time has Come, American Educational Research Association, Vol. 33, No. 7, p. 14-26. DOI: http://www.jstor.org/stable/3700093

Johnson, M. (2013) Attracting Young People into Construction Field Positions: Foundation of the Wall and Ceiling Industry. Available via: <https://www.coaa.org/Documents/About-COAA/Workforce-

Shortage/Attracting-Young-People-to-Construction-(AWCI).aspx > [Accessed: November, 2016].

Kellaway, R, Shackleton, J. and Al-Ali, L. (2016) Brexit and the Implications for UK Construction. Eversheds International. Available via: http://www.evershedssutherland.com/global/en/what/articles/index.page?ArticleID=en/Construction And_Engineering/Brexit_and the implications_for_UK_construction

[Accessed: May, 2017].

King, N. (1994)The Qualitative Research Interview: in Qualitative Methods in Organisational Research: A Practical Guide. Sage Publications: London. p.253. ISBN-10: 0803987706.

Kitzinger, J. (1994) The Methodology of Focus Groups: the Importance of Interaction Between Research Participants. Sociology of Health and Illness, Vol. 16, No. 1, pp. DOI: 10.1111/1467-9566.ep11347023. 
Koch, T. (2016) Before a Potential Brexit: European Immigration to the United Kingdom, its Relative benefits and Politico-Economic Implications, $\mathrm{PhD}$ Thesis, Johannes Gutenberg University Mainz, P.15. DOI: 10.13140/RG.2.1.1272.9204. Lancaster, G, Dodd, S. and Williamson, P. (2004) Design and Analysis of Pilot Studies: Recommendations for Good Practice, International Journal of Public Health Policy and Health Services Research, Vol. 10, No. 2, pp.307-312. DOI: 10.1111/j..2002.384.doc.x

Levack, M. (2012) Deepening Construction Crisis is Threatening UK Economic Recovery, Warns $\quad$ SBF. $\quad$ Available via: http://www.theconstructionalliance.org/news.php?pageNum_Recordset2=31\&to talRows_Recordset2 $=513 \& I D=330$ [Accessed: May, 2017].

Lewis-Beck, M. S, Bryman, A. and Futing Liao, T. (2004) Componential Analysis. The SAGE Encyclopedia of Social Science Research Methods, SAGE Publications: California. ISBN: 9780761923633; DOI: 10.4135/9781412950589

Mackenzie, S, Kilapatrick, A. and Akintoye, A. (2000) UK Construction Skills Shortage Response Strategies and an Analysis of Industry Perceptions, Construction Management and Economics, Vol 18, No. 7, pp.853-862. DOI: $10.1080 / 014461900433131$

Marley, C. (2016) Could Brexit End Procurement Red Tape? Building. Available via: http://www.building.co.uk/could-brexit-end-procurement-redtape?/5082234.article [Accessed: May, 2017].

Mathers, N, Fox, N. and Hunn, A. (2007) Surveys and Questionnaires, The NIHR Research Design Service For Yorkshire and the Humber, East Midlands: Yorkshire, National Institute for Health Research. Available via: https://www.rds-yh.nihr.ac.uk/wpcontent/uploads/2013/05/12_Surveys_and_Questionnaires_Revision_2009.pdf [Accessed: May, 2017].

McKay, S, Podro, S. and Dix, G. (2012) The Future Implications of Migrant Labour for Employment Relations. Advisory, Conciliation and Arbitration Service, ACAS. Available via: http://www.acas.org.uk/media/pdf/n/f/The_future_implications_of_migrant_lab our_for_employment_relationsL.pdf [Accessed: May, 2017]. 
McLeod, E. and Milne, K. (2016) The Brexit Effect: Impact on Construction and Infrastructure. Available Via: http://www.shepwedd.co.uk/knowledge/brexiteffect-impact-construction-infrastructure [Accessed: November, 2016].

Mcleod, S. (2014) Sampling Methods. Available via: www.simplypsychology.org/sampling.html [Accessed: November, 2016].

McLeod, E. and Milne, K. (2016) Brexit Analysis: Construction and Infrastructure, Shepherd and Weddernburn Available via: https://shepwedd.com/sites/default/files/Brexit_Analysis_Bulletin_Construction _Infrastructure.pdf [Accessed: May, 2017].

Metcalf, D, Coyle, D, Ruhs, M, Wadsworth, J. and Wilson, R. (2010) Skills Shortage Sensible: Review of Methodology, Migration Advisory Committee. Available via:

https://www.gov.uk/government/uploads/system/uploads/attachment_data/file/3 43446/MAC_Methodology_report.pdf [Accessed: November, 2016].

Migration Advisory Committee, (2014) Migrants in Low-skilled work: the Growth of EU and Non-EU labour in Low-skilled Jobs and its Impact on the UK Migration Advisory Committee. Available via: https://www.gov.uk/government/uploads/system/uploads/attachment_data/file/3 33083/MAC-Migrants_in_low-skilled_work_Full_report_2014.pdf [Accessed:

November, 2016].

Minford, P. and Lyons, G. (2016) EU Referendum: The Brexit Report. Independent Garage Association. Available via: http://independentgarageassociation.co.uk/uploads/documents/IGA_EU_Refere ndum_Series.pdf [Accessed: May, 2017].

Mohamed, S, Andrew, R.J, Dainty, S, Ison, P. and Bowen, H. (2008) Trends of Skills and Productivity in the UK Construction Industry, Engineering, Construction and Architectural Management, Vol. 15, No. 4, pp.372-382. DOI: http://dx.doi.org/10.1108/09699980810886865

Morley, L. (2001) Producing New Workers: Quality, Equality and Employability in Higher Education. Quality in Higher Education: Carfax Publishing, Vol. 7, No. 2, pp. 131-138. DOI: http://dx.doi.org/10.1080/13538320120060024

Morse, J. (1994) Critical Issues in Qualitative Research Methods. Thousand Oaks, SAGE Publications: California. ISBN-10: 0803950438 
Nakash, R, Hutton, J, Jørstad-Stein, E, Gates, S. and Lamb, S. (2006) Maximising Response to Postal Questionnaires - A Systematic Review of Randomised Trails, BMC Medical Research Methodology, Vol. 6, No. 5. DOI: 10.1186/1471-22886-5

O’Donnell, H, Karallis, T. and Sandelands, E. (2008) Reflecting on the Skills Agenda: a Construction Industry Perspective, Education and Training, Vol. 50, No. 1, pp. 59-63. DOI: http://dx.doi.org/10.1108/00400910810855522

Office for National Statistics, (2015) Labour Force Survey: Construction Workforce by Country of Birth, 2015. Available via:

http://www.ons.gov.uk/employmentandlabourmarket/peopleinwork/employmen tandemployeetypes/bulletins/uklabourmarket/2015-08-12 [Accessed: October, 2016].

Oliver, P. (2010) The Student's Guide to Research Ethics. 2nd Ed. McGraw-Hill International: Berkshire. ISBN: 0335210880

Oliver, T. (2016) Brexit: What Happens Next? The London School of Economics and Political Science, Strategic Update 16.2. Available via: http://www.lse.ac.uk/IDEAS/publications/reports/pdf/LSE-IDEAS-BrexitWhat-Next.pdf [Accessed: May, 2017].

Orogun, B. (2015) Managing Shortage of Skilled Labor trade in the Manitoba Construction Industry. Available via: http://www.academia.edu/15309925/Managing_Shortage_of_Skilled_Labor_tra de_in the_Manitoba_Construction_Industry [Accessed: May, 2017].

Palmer, K. (2016) Brexit will Widen 1.8m Engineering Skills Crisis, Industry Heavyweights Warn. Available via: http://www.telegraph.co.uk/business/2016/04/23/brexit-will-widen-18mengineering-skills-crisis-industry-heavywe/ [Accessed: October, 2016].

Patnaude, A. (2016) London Office Construction Booms Despite Brexit Uncertainty. Available via: https://www.wsj.com/articles/london-office-construction-boomsdespite-brexit-uncertainty-1462952347 [Accessed: January, 2017].

Pisani-Ferry, J, Röttgen, N, Sapir, A, Tucker, P and Wolff, G. (2016) Europe After Brexit: A Proposal for Continental Partnership. Bruegel Organisation. Available via: http://bruegel.org/2016/08/europe-after-brexit-a-proposal-for-a-continentalpartnership/ [Accessed: May, 2017]. 
Portes, J. (2016) Immigration, Free Movement and the EU Referendum, National Institute of Economic Review, Vol. 236, No. 1, p.14-22. DOI: https://doi.org/10.1177/002795011623600103

Reja, U, Lozar, K, Valentina, M, Vehovar, V. (2003) Open-ended vs Close-ended Questions in Web Questionnaires, Developments in Applied Statistics. Available via: http://www.stat-d.si/mz/mz19/reja.pdf [Accessed: May, 2017].

Rennie, A, Van-Teijlingein, E, Hundley, V. and Graham, W. (2001) The Importance of Conduction and Reporting Pilot Studies, International Journal of Public Health Policy and Health Services Research, Vol. 34, No. 3, pp.289-295. DOI: 10.1046/j.1365-2648.2001.01757.x

Rhodes, C. (2015) Construction Industry: Statistics and Policy, House of Commons Briefing Paper No. $01432 . \quad$ Available via: researchbriefings.parliament.uk/ResearchBriefing/Summary/SN01432 [Accessed: October, 2016].

(RICS) Royal Institution of Chartered Surveyors (2015) Skills Shortages and Financial Constraints Impede Growth but Demand Pipeline Remains Strong. Available via: http://www.rics.org/Global/RICS UK Construction market survey Q4-2015.pdf [Accessed: October, 2016].

(RICS) Royal Institution of Chartered Surveyors (2016) Q2 2016: RICS UK Construction Market Survey Construction Workloads Continue to Grow Slowly. Available via: http://www.rics.org/Global/RICS_UK_Construction_Market_Survey_Q2_2016 _economics.pdf [Accessed: October, 2016].

Rolfe, H. and Hudson-Sharp, N. (2016) The Impact of Free Movement on the Labour Market: Case Studies on Hospitality, Food Processing and Construction, National Institute of Economic and Social Research, pp.24-25. Available via: http://www.niesr.ac.uk/sites/default/files/publications/Free\%20movement\%20\%20Final\%20report.pdf [Accessed: May, 2017].

Rowley, J. (2014) Designing and Using Research Questionnaires, Management Research Review, Vol. 37, No. 3, pp. 308-330. DOI: http://dx.doi.org/10.1108/MRR-02-2013-0027

Ruhs, M. and Anderson, B. (2012) Who Needs Migrant Workers?: Labour Shortages, Immigration and Public Policy. Oxford University Press: Oxford. ISBN-10: 0199653615 
Ruiz, Y. (2004) Skills Shortage in Skilled Construction and Metal Trade Occupations, Labour Market Division: Office for National Statistics. Available via: file:///C:/Users/David/Downloads/skills_shortages_tcm77-160052.pdf [Accessed: May, 2015].

Somerville, W. (2016) When the Dust Settles: Migration Policy After Brexit. Migration Policy Institute. Available via: http://www.migrationpolicy.org/news/when-dustsettles-migration-policy-after-brexit [Accessed: October, 2016].

Springford, J. (2013) Is Immigration a Reason for Britain to Leave the EU? Centre for $\begin{array}{llll}\text { European } & \text { Reform. } & \text { Available }\end{array}$ https://www.cer.org.uk/sites/default/files/publications/attachments/pdf/2013/pb_ imm_uk_27sept13-7892.pdf [Accessed: May, 2017].

Steer, R. (2016) Only a Minor Brexit Vote Effects on Construction, Property Week. Available via: http://www.propertyweek.com/opinion/legal-views/only-a-minorbrexit-vote-effect-on-construction-\%E2\%80\%93-fingerscrossed/5084851.article Accessed: May, 2017].

Swales, D. and Baker, S. (2016) The Impact of Brexit on the UK Workforce, Agriculture and Horticulture Development Board, Horizon Market Intelligence. Available via: http://www.ahdb.org.uk/documents/Horizon_Brexit_Analysis_20September201 6.pdf [Accessed: May,2017].

Tashakkori, A. and Teddlie, C. (2003) Handbook of Mixed Methods in Social and Behavioural Research. Thousand Oaks, Sage Publications: California. ISBN-10: 0761920730

Tilford, S. (2016) Britain, Immigration and Brexit. Centre for European Reform, CER Bulletin. Available via: https://www.cer.org.uk/publications/archive/bulletinarticle/2015/britain-immigration-and-brexit [Accessed: May, 2017].

UKCES (UK Commission for Employment and Skills) (2014) The Labour Market Story: Skills for the Future. HM Government. Available via: http://www.employment-studies.co.uk/resource/labour-market-story-skillsfuture-0 [Accessed: May, 2017].

Van-Teijlingen, E. and Hundley, V. (2001) Social Research: The Importance of Pilot Studies. Nursing Standard, Vol. 16, No. 40, pp. 33-36. DOI: http://dx.doi.org/10.7748/ns2002.06.16.40.33.c3214 
Vargas-Silva, C. (2016) REPORT: Potential Implications of Admission Criteria for EU Nationals Coming to the UK. The Migration Observatory. Available via: http://www.migrationobservatory.ox.ac.uk/resources/reports/potentialimplications-of-admission-criteria-for-eu-nationals-coming-to-the-uk/ [Accessed: May, 2017].

Wasniowski, S. (2016) Brexit - Implications for the Construction Industry. Ashfords. Available via: http://www.ashfords.co.uk/article/brexit-implications-for-theconstruction-industry [Accessed: May, 2017].

Weddernburn, A. (2016) UK Construction Industry in a Post-Brexit Content, Willis Tower Watson: London. Available via: https://www.willistowerswatson.com/en/insights/2016/10/uk-constructionindustry-in-a-post-Brexit-context [Accessed: May, 2017].

Wheeler, B. and Hunt, A. (2016) Brexit: all you Need to Know about the UK Leaving the EU. Available via: http://www.bbc.co.uk/news/uk-politics-32810887 [Accessed: October, 2016].

Wilson, R. (2016) How Could Brexit Affect the UK's Construction Industry? Builder and Engineer. Available via: http://www.builderandengineer.co.uk/feature/howcould-brexit-affect-uks-construction-industry [Accessed: May, 2017].

Wood, J. (2016) How could Brexit Affect the UK's Construction industry? Builder and Engineer. p.4. Available via: http://www.builderandengineer.co.uk/feature/howcould-brexit-affect-uks-construction-industry [Accessed: May, 2017].

Woolley, M. (2009) Meeting the Mixed Methods Challenge of Integration in a Sociological Study of Structure and Agency, Journal of Mixed Methods Research, Vol. 3, No. 1. pp. 7-25. DOI: 10.1177/1558689808325774

Yin, R. K. (2006) Mixed Methods Research: Are the Methods Genuinely Integrated or Merely Parallel, Research in The Schools, Vol. 13, No. 1, pp. 41-47. DOI: http://web.archive.org/web/20100827031304/http://www.msera.org/Rits_131/Y in_131.pdf

Zimmerman, M. (1990) Assessing the Acceptability of NORPLANT Implants in Four Countries: Findings from Focus Group Research, Studies in Family Planning. Vol. 21, No. 1, pp. 92-103. DOI: 10.2307/196667 
Table 1 - Implications of Brexit on Skilled Labour

\begin{tabular}{|c|c|c|c|c|}
\hline Factors & Description & Positives & Negatives & References \\
\hline $\begin{array}{l}\text { Free movement } \\
\text { of people }\end{array}$ & $\begin{array}{l}\text { Free movement of people is } \\
\text { one of the European Union's } \\
\text { founding principles. It allows } \\
\text { any citizen of an EU country } \\
\text { to move freely across the } \\
\text { bloc for purposes of work. }\end{array}$ & $\begin{array}{l}\text { - Highly beneficial for the industry's skilled } \\
\text { labour force } \\
\text { - Recruitment of overseas labour addresses } \\
\text { the shortage of skilled labour } \\
\text { - EU labour can be used to meet } \\
\text { governmental construction projects (e.g. } \\
\text { HS2, housing projects) }\end{array}$ & $\begin{array}{l}\text { - Free movement is no longer perceived } \\
\text { to be a mutual arrangement between the } \\
\text { citizens of the UK and EU } \\
\text { - Immigration and the free movement of } \\
\text { people were heavily criticised during } \\
\text { the Brexit Campaign } \\
\text { - Free movement was used by the 'Leave } \\
\text { campaign' as the main reason for } \\
\text { leaving the EU, due to 'benefit tourism' } \\
\text { Citizens have a lack of confidence in the } \\
\text { government's ability to manage and } \\
\text { cope with migration }\end{array}$ & $\begin{array}{l}\text { Portes, } 2016 \\
\text { WeddernBurn, } 2016 \\
\text { Daly, } 2016 \\
\text { Springford, } 2013 \\
\text { Rolfe and Hudson- } \\
\text { Sharp, } 2016 \\
\text { Swales and Baker, } \\
2016\end{array}$ \\
\hline $\begin{array}{l}\text { EU skilled } \\
\text { labour }\end{array}$ & $\begin{array}{l}\text { Construction is a heavily } \\
\text { labour reliant sector. } \\
\text { Construction companies } \\
\text { have recruited EU skilled } \\
\text { labour in order to fill in } \\
\text { labour gaps due to issues } \\
\text { such as a shortage of skilled } \\
\text { labour and the need to } \\
\text { replace retiring baby- } \\
\text { boomers. }\end{array}$ & $\begin{array}{l}\text { - Addresses the shortage of UK skilled labour } \\
\text { - Used to replace retiring baby-boomers } \\
\text { - Used to meet governmental priority } \\
\text { projects. Beneficial for the industry's } \\
\text { skilled labour force } \\
\text { - Multi-skilled EU labour can provide } \\
\text { additional skill and knowledge to the UK } \\
\text { construction industry } \\
\text { EU labour are seen as having a superior work } \\
\text { ethic }\end{array}$ & $\begin{array}{l}\text { - } \quad \text { Classed as 'cheap' labour } \\
\text { - Potential for replacing British skilled } \\
\text { labour } \\
\text { Perceived by some British citizens as } \\
\text { - } \text { Stealing British jobs' } \\
\text { Seen as detrimental to the economy due } \\
\text { to 'benefit tourism' } \\
\text { Viewed as a near dominant form in the } \\
\text { industry }\end{array}$ & $\begin{array}{l}\text { Tilford, } 2016 \\
\text { Springford, } 2013 \\
\text { Ruhs and Anderson, } \\
2012 \\
\text { Somerville, } 2016 \\
\text { Goodwin and Heath, } \\
2016 \\
\text { Rolfe and Hudson- } \\
\text { Sharp, 2016 } \\
\text { McKay, et.al, } 2012 \\
\text { UKCES, 2014 }\end{array}$ \\
\hline
\end{tabular}


Table 2 - Brexit Situations

\begin{tabular}{|c|c|c|c|c|c|c|c|c|}
\hline \multicolumn{9}{|c|}{ Values } \\
\hline Brexit situations & 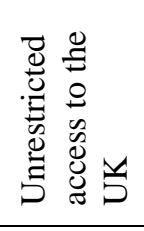 & 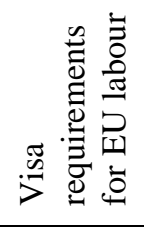 & 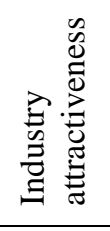 & 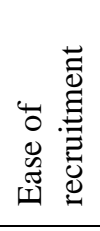 & $\underset{\frac{a}{a}}{\frac{a}{\vec{a}}}$ & 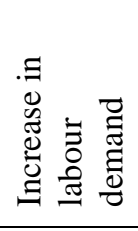 & 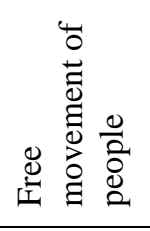 & 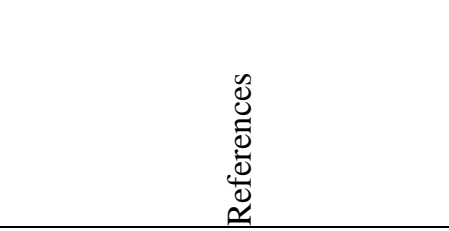 \\
\hline $\begin{array}{l}\text { Full EU } \\
\text { membership }\end{array}$ & $\checkmark$ & & $\checkmark$ & $\checkmark$ & & & $\checkmark$ & $\begin{array}{l}\text { Hiling, 2015; } \\
\text { Swales and Baker, 2016; and } \\
\text { Rolfe and Hudson-Sharp, } 2016\end{array}$ \\
\hline Soft Brexit & $\checkmark$ & & $\checkmark$ & $\checkmark$ & & & $\checkmark$ & $\begin{array}{l}\text { Swales and Baker, } 2016 \\
\text { Rolfe and Hudson-Sharp, } 2016 \\
\text { Wisniowski, } 2016 \\
\text { Koch, } 2016 \\
\text { Wilson, } 2016 \\
\text { Marley, } 2016\end{array}$ \\
\hline Hard Brexit & & $\checkmark$ & & & $\checkmark$ & $\checkmark$ & & $\begin{array}{l}\text { Swales and Baker, } 2016 \\
\text { Rolfe and Hudson-Sharp, } 2016 \\
\text { Wisniowski, } 2016 \\
\text { Koch, } 2016 \\
\text { Wilson, } 2016 \\
\text { Marley, } 2016\end{array}$ \\
\hline Current situation & $\checkmark$ & & $\checkmark$ & $\checkmark$ & & & $\checkmark$ & $\begin{array}{l}\text { Hiling, } 2015 \\
\text { Swales and Baker, } 2016 \\
\text { Rolfe and Hudson-Sharp, } 2016\end{array}$ \\
\hline
\end{tabular}


Figure 1 - Needs and Methods to Retain Skilled Labour

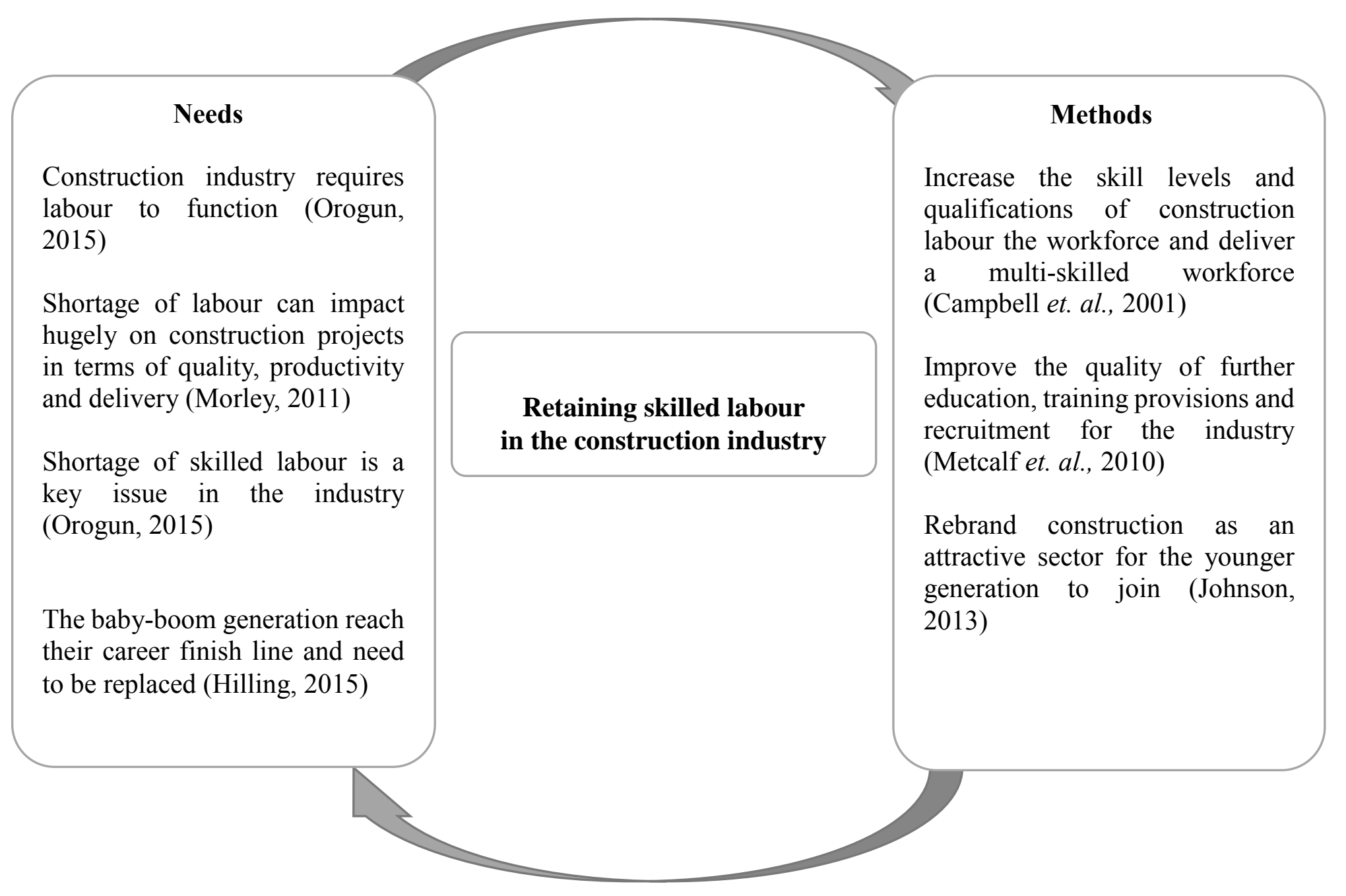


Table 3a - Years of Experience Accrued by Respondents

\begin{tabular}{lcccc}
\hline & $\begin{array}{c}\text { Frequency } \\
\text { (No.) }\end{array}$ & $\begin{array}{c}\text { Percent } \\
(\mathbf{\%})\end{array}$ & $\begin{array}{c}\text { Valid Percent } \\
(\mathbf{\%})\end{array}$ & $\begin{array}{c}\text { Cumulative Percent } \\
(\boldsymbol{\%})\end{array}$ \\
\hline No experience & 0 & 0 & 0 & 0 \\
$\leq$ 5 years & 6 & 11.8 & 11.8 & 11.8 \\
6-9 years & 23 & 45.1 & 45.1 & 56.9 \\
10-14 years & 9 & 17.6 & 17.6 & 74.5 \\
15-19 years & 5 & 9.8 & 9.8 & 84.3 \\
$\geq$ 20 years & 8 & 15.7 & 15.7 & 100 \\
Total & $\mathbf{5 1}$ & $\mathbf{1 0 0 . 0}$ & $\mathbf{1 0 0 . 0}$ & \\
\hline
\end{tabular}

Table 3b - Age Group of Participants

\begin{tabular}{lcccc}
\hline & $\begin{array}{c}\text { Frequency } \\
(\mathbf{N o .})\end{array}$ & $\begin{array}{c}\text { Percent } \\
(\mathbf{\%})\end{array}$ & $\begin{array}{c}\text { Valid Percent } \\
(\boldsymbol{\%})\end{array}$ & $\begin{array}{c}\text { Cumulative Percent } \\
(\boldsymbol{\%})\end{array}$ \\
\hline Under 21 & 2 & 3.9 & 3.9 & 3.9 \\
$21-24$ & 1 & 2.0 & 2.0 & 5.9 \\
$25-35$ & 26 & 51.0 & 51.0 & 56.9 \\
$36-44$ & 9 & 17.6 & 17.6 & 74.5 \\
$45-54$ & 6 & 11.8 & 11.8 & 86.3 \\
$55-64$ & 7 & 13.7 & 13.7 & 100.0 \\
Total & $\mathbf{5 1}$ & $\mathbf{1 0 0 . 0}$ & $\mathbf{1 0 0 . 0}$ & \\
\hline
\end{tabular}

Table 3c - Professional Occupation

\begin{tabular}{lcccc}
\hline & $\begin{array}{c}\text { Frequency } \\
(\mathbf{N o .})\end{array}$ & $\begin{array}{c}\text { Percent } \\
(\mathbf{\%})\end{array}$ & $\begin{array}{c}\text { Valid Percent } \\
(\mathbf{\%})\end{array}$ & $\begin{array}{c}\text { Cumulative Percent } \\
(\mathbf{\%})\end{array}$ \\
\hline Clerk of works & 2 & 3.9 & 3.9 & 3.9 \\
Consultant & 4 & 7.9 & 7.9 & 11.8 \\
Designers & 2 & 3.9 & 3.9 & 15.7 \\
Engineer & 3 & 5.9 & 5.9 & 21.6 \\
Labour & 5 & 9.8 & 9.8 & 31.4 \\
Manager & 13 & 25.5 & 25.5 & 56.9 \\
Surveyor & 22 & 43.1 & 43.1 & 100 \\
Total & $\mathbf{5 1}$ & $\mathbf{1 0 0 . 0}$ & $\mathbf{1 0 0 . 0}$ & \\
\hline
\end{tabular}


Table 4 - Dichotomous Questions and Responses

\begin{tabular}{lll}
\hline & $\begin{array}{l}\text { Number of } \\
\text { respondents to each } \\
\text { corresponding } \\
\text { dichotomous question } \\
\text { (No.) }\end{array}$ & $\begin{array}{l}\text { Nes } \\
\text { No }\end{array}$ \\
\hline & 45 & 6 \\
Q1) Does a shortage of skilled labour affect the performance of the UK construction industry? & 45 & 6 \\
Q2) Do you believe that the UK construction industry relies on European skilled labour? & 7 \\
Q3) Do you expect to see an increase in demand for skilled labour in the construction industry & 44 & 7 \\
post-Brexit? & & \\
\hline
\end{tabular}


Table 5 - Likert Scale Questions and Responses

\begin{tabular}{|c|c|c|c|c|c|}
\hline \multirow[t]{2}{*}{ Questions } & \multicolumn{5}{|c|}{$\begin{array}{c}\text { Number of respondents to each } \\
\text { corresponding Likert item } \\
\text { question (No.) }\end{array}$} \\
\hline & 1 & 2 & $\mathbf{3}$ & 4 & 5 \\
\hline ttractive for skilled labour post-Brexit & & & 5 & 21 & 25 \\
\hline ficial for the UK construction industry & 29 & 18 & 2 & 2 & - \\
\hline ttractive than other European construction industries for & 43 & 3 & 2 & 3 & - \\
\hline crease & 21 & 9 & 5 & 10 & 6 \\
\hline late & 2 & 10 & 3 & 30 & 6 \\
\hline & 47 & 2 & 2 & - & - \\
\hline & 3 & 12 & 2 & 5 & 29 \\
\hline & 22 & 20 & 3 & 3 & 3 \\
\hline try will decrease & 8 & 19 & 12 & 9 & 3 \\
\hline
\end{tabular}

Q4) The UK construction industry will be attractive for skilled labour post-Brexit

Q5) The free movement of people was beneficial for the UK construction industry

Q6) UK construction industry will be less attractive than other European construction industries for EU labour

Q7) Quality of construction projects will decrease

Q8) Construction projects will be delivered late

Q9) Access to skilled labour will be reduced

Q10) Fall in projects

Q11) Not meeting governmental projects

Q12) Growth for the UK construction industry will decrease

NB: where: $1=$ strongly agree; $2=$ agree; $3=$ neutral; $4=$ disagree; and $5=$ strongly disagree. 
Figure 3 - Linkage Between Literature and Personnel Factors

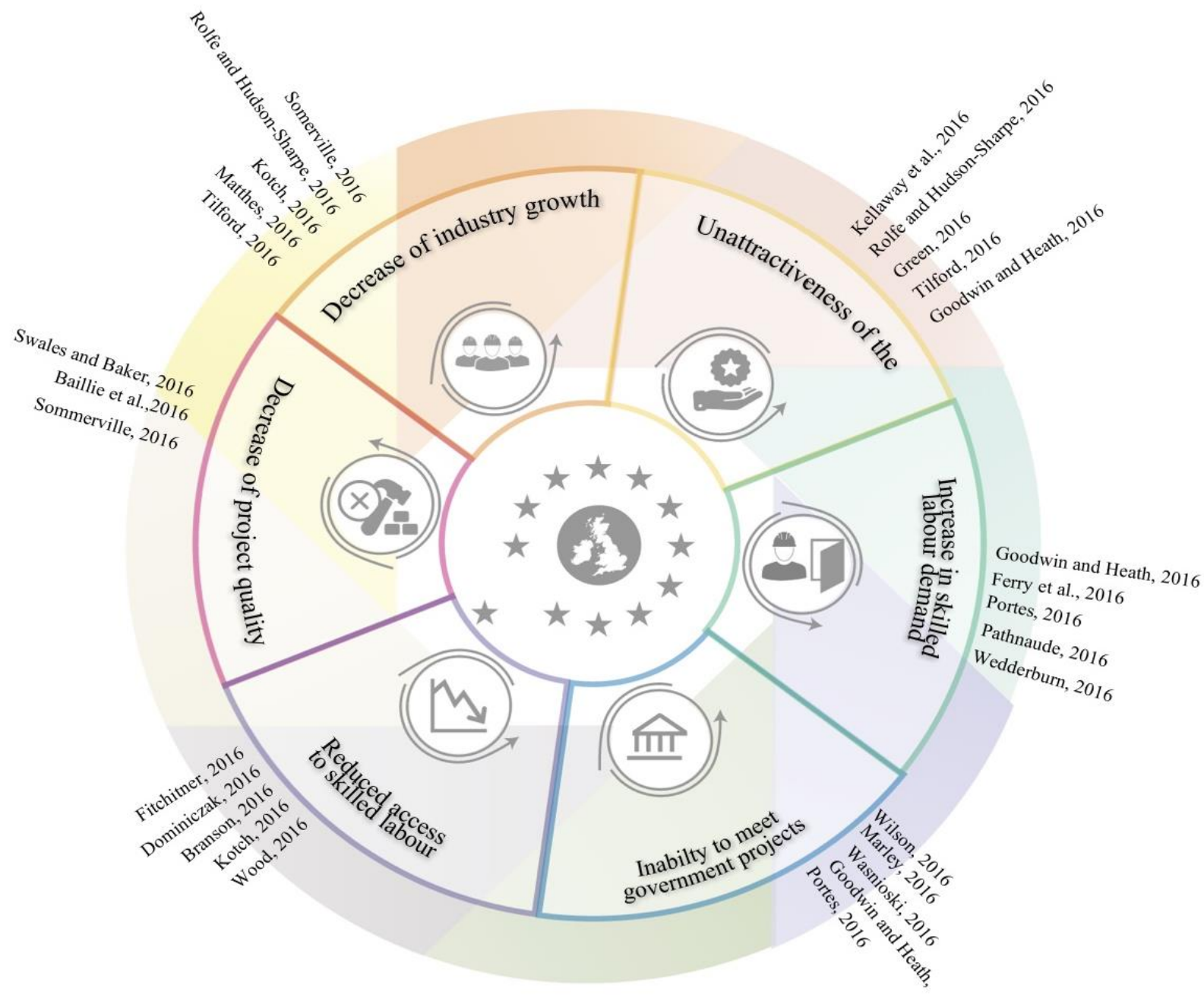

